\title{
Phenotypic and molecular screenings for determination of cassava mosaic disease (CMD) status in farmers' fields in Ebonyi State, Nigeria
}

\author{
David Okeh Igwe ${ }^{1,2}$ (C) Chidinma Blessing Anyanwu ${ }^{1} \cdot$ Celestine Azubuike Afiukwa ${ }^{1}$. Catherine Veronica Nnamani ${ }^{3}$. \\ Friday Nwalo Nweke ${ }^{4}$. George Nkem Ude ${ }^{5}$. Benjamin Ewa Ubi ${ }^{1}$
}

Received: 9 September 2020 / Accepted: 27 November 2020 / Published online: 10 December 2020

(c) The Author(s), under exclusive licence to Springer Nature B.V. part of Springer Nature 2020

\begin{abstract}
African cassava mosaic virus (ACMV) and East African cassava mosaic virus (EACMV) are among the major constraints to cassava productivity within tropical and sub-tropical regions, including Ebonyi State, Nigeria. Thus, virus indexing has become imperative to determine the status of cassava mosaic disease (CMD) in Ebonyi State, to implement appropriate preventive and control strategies. Seventy-eight cassava accessions obtained from different locations of Ebonyi State were phenotypically scored, using scales 1-5 depending on CMD symptomatic expressions, followed by multiplex-PCR and sequencing for validation. 11\% of cassava accessions cultivated in Afikpo were resistant (RE) to ACMV compared to 8\% of moderately-resistant (MR) accessions in Izzi and 55\% of tolerant (TO) ACMV accessions in Ebonyi. 100\% of cassava accessions in Onicha and 66\% in Afikpo South were susceptible (SU) and highly susceptible (HS) to ACMV, respectively. With multiplex-PCR, 97.4\% (ACMV) and 2.6\% (EACMV) were positive. Dunn's multiple comparison tests of CMD mean incidence demonstrated differences $(\mathrm{P}<0.05)$, except between RE and MR, and TO and MR. More transitions $(\mathrm{A} / \mathrm{G}, \mathrm{C} / \mathrm{T})$ compared to transversions (A/T, G/T), were detected, with nonsynonymous mutations (Leucine/Isoleucine; Valine/Isoleucine; Arginine/Lysine; Methionine/Isoleucine), and good bit-scores (91.13-99.07\% identites; e-values of $7.00 \mathrm{e}^{-148}-0.00 \mathrm{e}^{+00}$ ). Phylogeny resolved the sequences into five major groups. DNA sequencing validated the detected ACMV and EACMV species. This study revealed variants of ACMV and low adoption of RE and MR cassava accessions in the farmers' fields. The findings will guide in getting disease-free and resistant varieties as planting materials to significantly mitigate the CMD spread in Ebonyi State, Nigeria.
\end{abstract}

Keywords Manihot esculenta $\cdot$ Symptoms $\cdot$ Multiplex-PCR $\cdot$ Phylogeny $\cdot$ African cassava mosaic virus

Supplementary information The online version of this article (https://doi.org/10.1007/s11033-020-06039-5) contains supplementary material, which is available to authorized users.

David Okeh Igwe

dave25dato@yahoo.com; doi3@ cornell.edu

1 Department of Biotechnology, Ebonyi State University, Abakaliki, Ebonyi, Nigeria

2 Boyce Thompson Institute for Plant Research, Ithaca, NY 14853, USA

3 Plant Taxonomy and Conservation Biology Research Unit, Department of Applied Biology, Presco Campus, Ebonyi State University, Abakaliki, Nigeria

4 Biology/Microbiology/Biotechnology, Faculty Science, Federal University, Ndufu-Alike Ikwo (FUNAI), Ikwo, Ebonyi, Nigeria

5 Department of Natural Sciences, Bowie State University, Bowie, USA

\section{Background}

Cassava (Manihot esculenta Crantz), family Euphorbiaceae, is a major food crop in sub-Saharan Africa (SSA) [1, 2]. The crop provides the bulk of dietary calories to hundreds of millions of households and serves as a bioenergy crop for industrial utilization and source of income generation to farmers [3-5]. This staple crop plays other significant roles including sustainability to food security, provision of employment opportunities, and provision of potential raw materials for generating starch, alcoholic beverages, pharmaceuticals, gums, confectioneries, livestock feed, as well as its use as a vegetable [5, 6]. Cassava possesses characteristics of high-water content, bulkiness, easy spoilage, and ability to withstand drought condition. One of the favourable attributes of cassava is its ability to produce reasonable yield under marginal growth conditions of low soil fertility 
and moisture stress [7]. Cassava production is estimated to be about 37.5 million tonnes with yields up to the tune of 12 tonnes per hectare and area of 3.13 million hectares [8, 9]. However, biotic stresses, including pests and cassava mosaic disease (CMD), limit the growth, development and production of cassava to an average of 15 tons per hectare worldwide and 10.9 t/ha in Africa [10]. Cassava mosaic disease, the major constraint to cassava production in Africa, is caused by a number of distinct cassava mosaic geminiviruses (CMGs, family Geminiviridae and genus Begomovirus). The disease is prevalent across all cassava growing regions of SSA [3], but pandemic to East and Central Africa posing serious threats to cassava production [11-13].

Nine CMGs associated with CMD have been identified and they include African cassava mosaic virus (ACMV), East African cassava mosaic virus (EACMV), East African cassava mosaic Cameroon virus (EACMCV), East African cassava mosaic Kenya virus (EACMKV), East African cassava mosaic Malawi virus (EACMMV), East African cassava mosaic Zanzibar virus (EACMZV), South African cassava mosaic virus (SACMV), African cassava mosaic Burkina Faso virus (ACMBFV), and Cassava mosaic Madagascar virus (CMMGV) [9, 13-19]. Although cassava begomoviruses, which cause CMD, are naturally transmitted by the whitefly virus-vector, Bemisia tabaci, they are also disseminated through mechanical means (grafting) [20] and stem cuttings used for vegetative propagation [21]. Other activities that facilitate the spread of CMD include prolonged cropping cycle, total reliance on morphology and clonal propagation which inevitably leads to build up of inocula prior to symptomatic expressions [3, 22-24]. The compounding effects of this devastating disease include: its variable symptomatic expressions on cassava leaves (even on the same genotypes) possibly associated with the level of susceptibility of the cassava plants to the virus attack; age of the plants; environmental stressors; strains of the virus; and population of $B$. tabaci within the studied locations, and these factors contribute to the spread of the disease in cassava production zones [25-27]. Control strategies that are applicable to CMD have been reviewed and the use of disease-free and resistant cassava varieties have been advocated to be the best approaches in mitigating the spread and effects of CMD [28-32]. These CMGs can occur as single or mixed virus infections, but the most disturbing about the character of the virus is its latent period, which poses a great challenge in rapid detection based on the morphological appearance of the infected stem cuttings prior to use as planting materials by farmers, leading to huge losses in cassava yields [33-35]. For preventive and effective control measures to be adopted to reduce the distribution of the virus, a rapid, cost-effective and reliable method is required. Identification and characterization of the different viruses of cassava based on symptom development could be misleading and ineffective in controlling the disease. Different tools such as immunological and use of nucleic acid methods are potential and sensitive techniques in detecting the viruses. Therefore, multiplex PCR and DNA sequencing, in addition to morphological method was applied in determining the status of CMD on the farmers' fields within the different Local Government Areas (LGAs) of Ebonyi State, Nigeria.

\section{Materials and methods}

\section{Sample collection}

Cassava samples were purposefully collected from three geopolitical zones in Ebonyi state, namely, Ebonyi North, Ebonyi Central, and Ebonyi South zones (Fig. 1 and Supplementary Table S1) during cassava planting season. The LGAs covered in each of the zones were: Ohaukwu, Izzi, Ebonyi, and Abakaliki (Ebonyi North zone); Ezza North, Ezza South and Ikwo (Ebonyi Central zone); and Onicha, Afikpo North, and Afikpo South (Ebonyi South zone). The number of locations sampled in each LGA ranged from 1 to 14. A scoring scale was used in the process in order to accurately score the symptom severity of the virus on the cassava leaves. The scoring pattern was rated from 1 to 5 , depending on the symptom severity of the virus on the cassava leaves. For instance, scale $1=$ no visible symptoms (resistant), scale $2=$ mild chlorotic patterns over the whole leaf or mild distortion at the leaf base (moderately resistant), scale $3=$ mosaic patterns throughout the leaf part and leaf distortion of the lower part of the leaf (tolerant), scale $4=$ mosaic pattern of two-thirds on the leaf, distortion and general reduction in leaf size (susceptible), and scale $5=$ severe mosaic, twisted leaf and stunting of the whole plant (highly susceptible) [36, 37].

\section{DNA extraction}

Seventy-eight (78) M. esculenta accessions were collected from different LGAs in Ebonyi State of Nigeria and used for DNA extraction. Aproximately, $100 \mathrm{mg}$ of fresh young leaves of M. esculenta accessions were collected from different farmers' fields for DNA extraction using a modified Cetyltrimethylammonium bromide (CTAB) method [38]. The young leaves of symptomatic and some asymptomatic cassava samples were collected and weighed to obtain approximately $150-200 \mathrm{mg}$ before grinding thoroughly with $200 \mu \mathrm{l}$ of CTAB buffer using clean and sterilized pestles and mortars. Each was later made up to $700 \mu$ with CTAB buffer and the mixture was transferred to $1.5 \mathrm{ml}$ microcentrifuge tube for proper mixing and vortexing. The mixture was incubated at $60^{\circ} \mathrm{C}$ for $15 \mathrm{~min}$ after which it was brought to room temperature for addition of equal volume of phenol, 


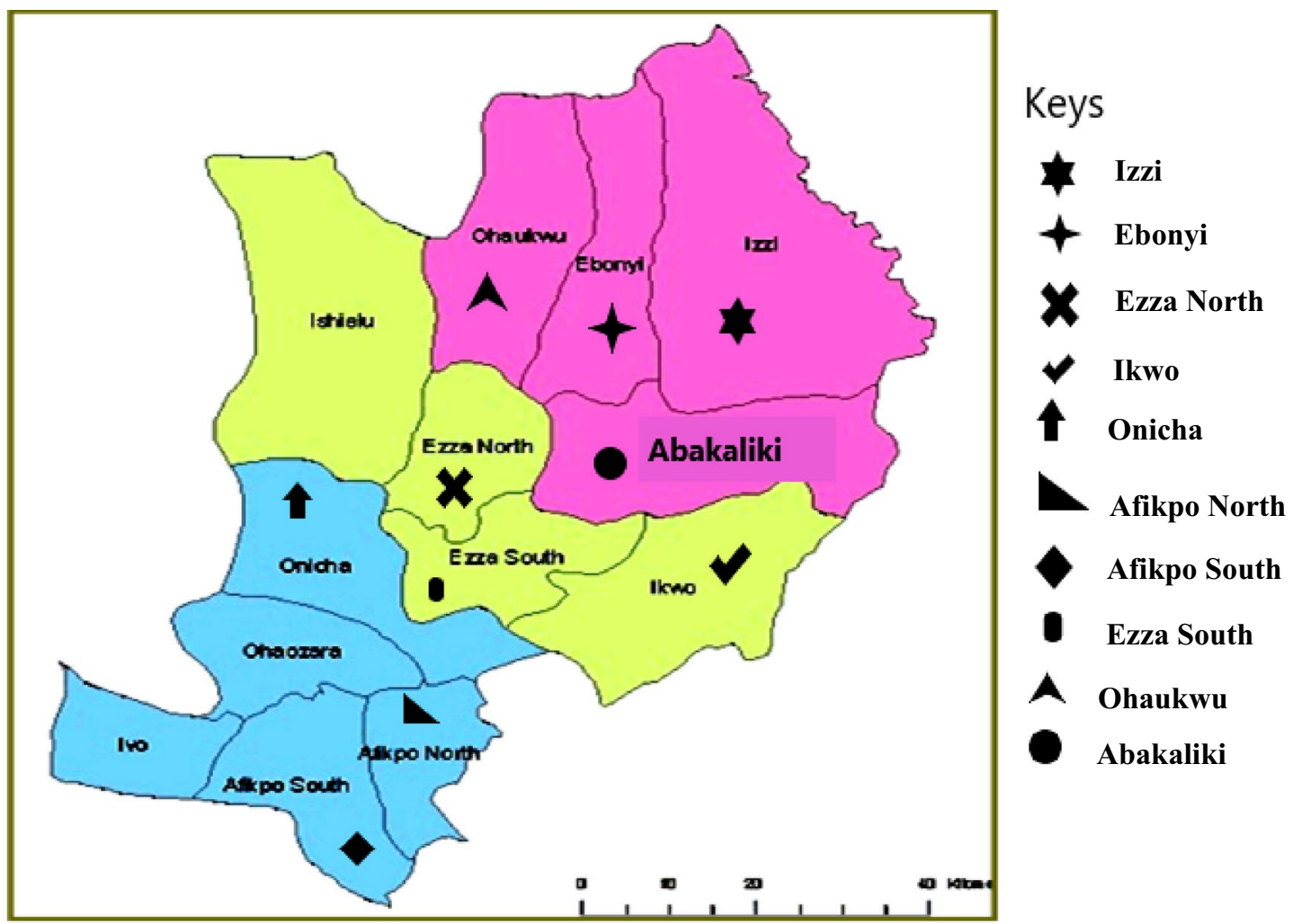

Fig. 1 Map of Ebonyi State, Nigeria, showing different Local Government Areas (LGAs) used for the sample collection ( Source https://www. ebonyionline.com/wp-content/uploads/2013/02/map-of-ebonyi-state_2.gif)

chloroform and isoamyl alcohol in the ratio of 25:24:1. It was thoroughly mixed and centrifuged at 13,000 revolutions per minute (rpm) for $15 \mathrm{~min}$. After the centrifugation, $450 \mu \mathrm{l}$ of the supernatant was transferred into a new and sterile $1.5 \mathrm{ml}$ microcentrifuge tube followed by addition of $400 \mu \mathrm{l}$ of ice-cold isopropanol for precipitation of the DNA. It was mixed by gentle inversion and incubated at $-20{ }^{\circ} \mathrm{C}$ overnight. At the end of the overnight incubation, it was centrifuged at 14,000 rpm for $15 \mathrm{~min}$ to sediment the DNA. The supernatant was well decanted without disturbing the pellet. The pellet was washed by adding $700 \mu$ of $70 \%$ ethanol and centrifuging at 13,000 rpm for $5 \mathrm{~min}$. The ethanol was decanted followed by air-drying the pellet and suspension in $100 \mu \mathrm{l}$ of nuclease-free water.

\section{Polymerase chain reaction and agarose gel electrophoresis}

PCR amplification of the extracted DNA samples with ACMV and EACMV specific primers consisted of $2.0 \mu \mathrm{l}$ of $100 \mathrm{ng} / \mathrm{ul}$ DNA, $2.5 \mu \mathrm{l}$ of $10 \times$ buffer (Bioline, Taunton, USA), $1.5 \mu \mathrm{l}$ of $50 \mathrm{mM} \mathrm{MgCl}{ }_{2}$ (Bioline, Taunton, USA), $2.0 \mu \mathrm{l}$ of $2.5 \mathrm{mM}$ dNTPs (Bioline, Taunton, USA), $0.2 \mu \mathrm{l}$ of 500U DNA Taq polymerase (Bioline, Taunton, USA), $1.0 \mu \mathrm{l}$ of $10 \mathrm{pm}$ each of the ACMV (OjaRep-F: CRTCAATGACGT
TGTACCA; ACMVRep-R: CAGCGGMAGTAAGTCMGA) and EACMV (OjaRep-F: CRTCAATGACGTTGTACCA; EACMVRep-R: GGTTTGCAGAGAACTACATC) primers [39] and was made up to total volume of $25 \mu$ by adding $13.05 \mu \mathrm{l}$ of DEPC-treated water (Invitrogen Corporation, USA). The PCR cycling profile for the reaction consisted of an initial step at $94{ }^{\circ} \mathrm{C}$ for $5 \mathrm{~min}$., 35 cycles of $94{ }^{\circ} \mathrm{C}$ for $40 \mathrm{~s}, 55^{\circ} \mathrm{C}$ for $1 \mathrm{~min}$, and $72{ }^{\circ} \mathrm{C}$ for $1 \mathrm{~min}$., and $8 \mathrm{~min}$ final extension at $72{ }^{\circ} \mathrm{C}$. Five (5) $\mu \mathrm{l}$ of the PCR products were electrophoresed in $1.5 \%$ agarose gel containing $0.5 \mathrm{mg} / \mathrm{ml}$ ethidium bromide and photographed on Transilluminator UV light (Fotodyne Incorporated, Analyst Express, USA).

\section{Purification of PCR amplicons and DNA sequencing}

The amplified PCR products that generated a single product were purified using ethanol protocol [40] with slight modifications. Briefly, $40 \mu \mathrm{l}$ of $100 \%$ ethanol was added to $20 \mu \mathrm{l}$ of the PCR products, incubated at room temperature for $15 \mathrm{~min}$ and centrifuged at $12,000 \mathrm{rpm}$ for $15 \mathrm{~min}$. The ethanol was carefully decanted and $100 \mu \mathrm{l}$ of $70 \%$ of ethanol was used to wash, maintaining the same centrifugal speed and time. The ethanol was discarded, and the DNA dried at room temperature for resuspension using $20 \mu \mathrm{l}$ of DEPC-treated water. To rule out shortcomings linked to the utilization of only a 
PCR-based technique as a conclusive detection of CMD in field-collected samples [39, 41, 42], nine LGAs (Ikwo, Ezza North, Ezza South, Afikpo North, Afikpo South, Ebonyi, Abakaliki, Ohaukwu and Izzi) were targeted and 2-4 representative samples were randomly selected from each of the LGAs for DNA sequencing. The purified samples were sequenced at BioScience Center, International Institute of Tropical Agriculture, IITA, Ibadan, Nigeria.

\section{Data analysis}

\section{Sequence data analysis}

The mean incidence and bar chart of scored CMD obtained from symptomatic cassava accessions were analysed in Microsoft Excel 2016. To ascertain the level of siginificance and pairwise comparison of the mean CMD incidence, Kruskal-Wallis rank and Dunn's tests, incoporated in $\mathrm{R}$ package, were used. The raw sequences generated from ABI Prism 3130X1 Genetic automated sequencer (Applied Biosystems) were carefully edited, filtered, translated to amino acid and assembled for polymorphism detection using CodonCode Aligner version 6.0 (CodonCode, Centerville, MA). Sequence alignment was performed with ClastalW and BioEdit version 7. 2. 5 [43]. Other related analyses such as multiple and pairwise alignments using ClustalW were included. The Basic Local Alignment Search Tool (BLAST) version 2.0, of the National Center for Biotechnology Information found at https://blast.ncbi.nlm.nih.gov/Blast.cgi was used to search for species identification, sequence similarity or homology and other bit scores. In addition, MEGA 10 software was used for phylogenetic reconstruction with Maximum Likelihood (ML) option with 1000 bootstrapping iterations [44]. Pairwise sequence comparisons were computed using Sequence Demarcation Tool (SDT) v. 1.2 [45], with the MUSCLE [46] alignment option with 94\% cutoff, as utilized in species separation of begomoviruses [47].

\section{Results}

\section{Virus indexing/scoring in the famers' fields}

Within the sampled locations including Ikwo, Abakaliki, Ebonyi, Ohaukwu, Afikpo North, Afikpo South and Onicha in Ebonyi State, Nigeria, most of the sampled farmers' fields were heavily infected with the CMD. Only few were scored for 1 , which indicates resistance, while most of the identified severity of the symptomatic expressions of the CMD were in the tolerant and susceptible ranges (scales 3-5) (Supplementary Table S2). The scales were strictly adhered to in order to identify those exhibiting any of the symptoms of mild chlorotic patterns, leaf distortion, mosaic patterns on leaves, general reduction in leaf sizes, severe mosaic, twisted leaves and stunting of the whole plant (Fig. 2).

\section{Percentage incidence of phenotypic symptom severity of cassava mosaic disease on local accessions of Manihot esculenta in farmers' fields}

The mean percentage incidence of ACMV and EACMV detected on the cassava accessions varied from one LGA to another depending on the symptom severity caused by the viruses. The mean percentage of resistant (RE) M. esculenta accessions varied from $0.1 \%$ (Izzi) to $11 \%$ (Afikpo North), while Ezza North, Ebonyi, Ohaukwu, Afikpo South and Onicha recorded no RE (Table 1 and Fig. 3). For moderately-resistant (MR) accessions, the incidence varied from 2\% (Ebonyi) to $8 \%$ (Izzi), while Ezza North, Ezza South, Ohaukwu, Afikpo North, Afikpo South and Onicha had no cassava accession that was MR. The incidence (mean percentage) of tolerant (TO) accessions ranged from $12 \%$ (Izzi) to $53 \%$ (Ebonyi) and it was noted in almost all the sampled LGAs, except Onicha. The susceptible (SU) ones ranged from $17 \%$ (Abakaliki) to $100 \%$ (Onicha), with only Afikpo South having none as susceptible. For the highlysusceptible (HS) accessions, the CMD mean incidence was from $27 \%$ (Ikwo) to $66 \%$ (Afipko South), but no such incidence was recorded in Ezza North, Ebonyi and Onicha LGAs. Also, pairwise comparison of the CMD incidence revealed significant differences $(\mathrm{P}<0.05)$ among the scored incidences of severity (HS and RE had $\mathrm{P}=2.4 \mathrm{e}^{-11}$; $\mathrm{MR}$ and $\mathrm{HS}=5.6 \mathrm{e}^{-07} ; \mathrm{SU}$ and $\mathrm{RE}=1.6 \mathrm{e}^{-07} ; \mathrm{SU}$ and $\mathrm{HS}=1.6 \mathrm{e}^{-07} ; \mathrm{SU}$ and $\mathrm{MR}=0.0125 ; \mathrm{TO}$ and $\mathrm{RE}=0.00022$; $\mathrm{TO}$ and $\mathrm{RE}=0.001596$; $\mathrm{TO}$ and $\mathrm{HS}=1.8 \mathrm{e}^{-10}$; and $\mathrm{TO}$ and $\mathrm{SU}=7.5 \mathrm{e}^{-06}$ ), except between MR and RE, and TO and MR (Table 2).

\section{Detection of ACMV and EACMV using a multiplex-PCR based molecular technique}

To confirm the phenotypic results of the CMD incidence, a multiplex PCR-based technique was utilized to identify the accessions that were infected with ACMV and EACMV. Out of the 78 samples obtained from the 10 different LGAs of Ebonyi State, 11 of them, which had no symptoms but were purposefully included to serve as negative controls, tested negative for both ACMV and EACMV (Supplementary Table S2; Fig. 4). The negative controls were obtained from Abakaliki (Ebia Unuphu3), Ezza South (Amuzu2EzS2, Amuzu4EzS4, Onuek3EzS3, Onuek5EzS5, Onuek6EzS6, Onuek8EzS8,), Ikwo (Onyik1Ikw21, Ameka1Ikwo1), Afikpo North (AfikpoNAm3) and Ebonyi (Ugwua6Eb6). An infection of both ACMV and EACMV was detected in Afikpo North (Afikpo North3, and Afikpo North4) on separate plants. 




Fig. 2 Representation of scales used in the scoring/indexing of cassava mosaic viruses: Scale 1 no visible symptoms (Resistant, RE), Scale 2 mild chlorotic patterns over the whole leaf or mild distortion at the leaf base (moderately resistant, MR), Scale 3 mosaic patterns throughout the leaf part and leaf distortion of the lower part of the leaf (tolerant, TO), Scale 4 mosaic pattern of two-thirds on the leaf, distortion and general reduction in leaf size (susceptible, SU) and Scale 5 severe mosaic, twisted leaf and stunting of the whole plant (highly susceptible, HS)
Table 1 Mean percentage of cassava mosaic disease (CMD) detected in different locations of Ebonyi State

\begin{tabular}{lllllll}
\hline Location & \multicolumn{9}{l}{ Mean percentage of Cassava mosaic disease incidence } & Virus type \\
\cline { 2 - 6 } & RE $(\%)$ & MR $(\%)$ & TO $(\%)$ & SU $(\%)$ & HS (\%) & \\
\hline Izzi & 0.1 & 8 & 12 & 30 & 40 & ACMV \\
Abakaliki & 0.1 & 3 & 33 & 17 & 47 & ACMV \\
Ezza North & - & - & 18 & 82 & - & ACMV \\
Ezza South & 1 & - & 39 & 25 & 35 & ACMV \\
Ikwo & 0.1 & 3 & 15 & 55 & 27 & ACMV \\
Ebonyi & 2 & - & 53 & 45 & - & ACMV \\
Ohaukwu & - & - & 21 & 34 & 45 & ACMV \\
Afikpo North & 11 & - & 48 & - & 41 & ACMV \\
Afikpo North & - & - & 40 & 60 & - & EACMV \\
Afikpo South & - & - & 34 & - & 66 & ACMV \\
Onicha & - & - & - & 100 & - & ACMV \\
\hline
\end{tabular}

$R E$ resistant, $M R$ moderately resistant, $T O$ tolerant, $S U$ susceptible, $H S$ highly susceptible, ACMV African cassava mosaic virus, EACMV East African cassava mosaic virus 
Fig. 3 Mean percentage incidence of symptom severity score on cassava accessions infected with cassava mosaic disease (CMD). Resistant $=$ no visible symptoms; moderately resistant $=$ mild chlorotic patterns over the whole leaf or mild distortion at the leaf base; tolerant $=$ mosaic patterns throughout the leaf part and leaf distortion of the lower part of the leaf; susceptible $=$ mosaic pattern of two-thirds on the leaf, distortion and general reduction in leaf size; and highly susceptible $=$ severe mosaic, twisted leaf and stunting of the whole plant

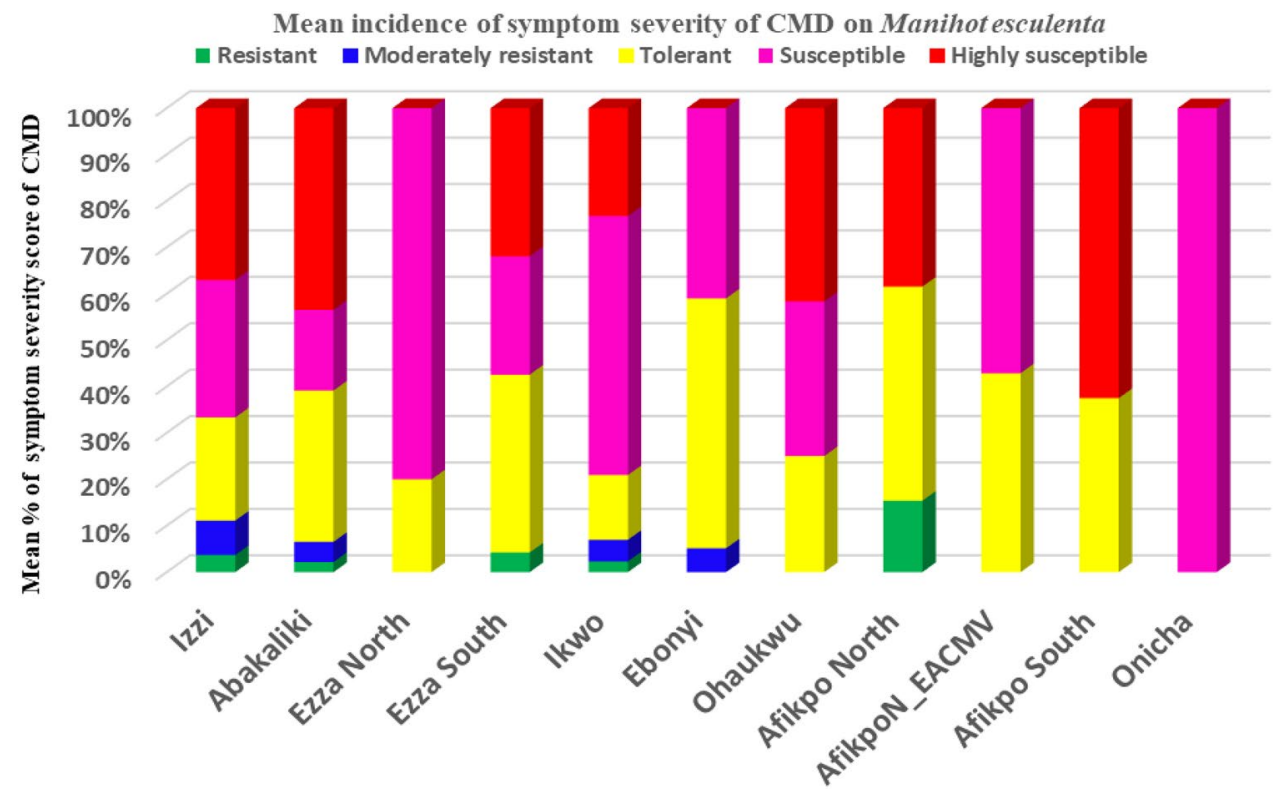

Table 2 Pairwise comparisons of incidence of cassava mosaic disease (CMD) using Dunn's test option

\begin{tabular}{lllll}
\hline & RE & HS & MR & SU \\
\hline HS & $2.4 \mathrm{e}^{-11}$ & - & - & - \\
MR & 0.68563 & $5.6 \mathrm{e}^{-07}$ & - & - \\
SU & $1.6 \mathrm{e}^{-07}$ & 0.01250 & 0.00022 & - \\
TO & 0.01596 & $1.8 \mathrm{e}^{-10}$ & 0.15356 & $7.5 \mathrm{e}^{-06}$ \\
\hline
\end{tabular}

For test of normality in distribution, Shapiro-Wilk normality test $\left(\mathrm{W}=0.87929, \mathrm{P}\right.$ value $=2.312 \mathrm{e}^{-06}$ ) was used; Bartlett's test $\left(\mathrm{K}\right.$-squared $=\mathrm{Inf}, \mathrm{df}=4, \mathrm{P}$ value $\left.<2.2 \mathrm{e}^{-16}\right)$ for homogeneous variance; Levene's test $(\mathrm{df}=4, \mathrm{~F}$ value $=0.5493$ and $\operatorname{Pr}(>\mathrm{F})=0.7001)$ for homogeneity of variance (center $=$ median), followed by KruskalWallis rank test $\left(\right.$ Chi squared $=76.264, \mathrm{df}=4, \mathrm{P}$ value $=1.077 \mathrm{e}^{-15}$ ) to determine the level of significance

$R E$ resistant, $M R$ moderately resistant, $T O$ tolerant, $S U$ susceptible; $H S$ highly susceptible

\section{Sequence alignment}

The aligned representative sequences obtained from the cassava accessions that tested positive to ACMV demonstrated polymorphisms at different consensus positions (Supplementary Fig. S1). A total of 10 transitional mutations (interchange of purine or of pyrimidine bases: $\mathrm{A} \leftrightarrow \mathrm{G}$ and $\mathrm{C} \leftrightarrow \mathrm{T}$ ) and six transversional mutations (interchange of purine and pyrimidine bases: $\mathrm{A} \leftrightarrow \mathrm{T}$ and $\mathrm{G} \leftrightarrow \mathrm{T}$ ) were identified at different positions. For instance, at consensus position 79, a transitional mutation occurred, in which the CMGs isolated from cassava accessions EbiaUAi16, Nkwag1 Ai17 and Presco2_Ai had G nucleotide, while the CMG genomes isolated from the rest of the accessions had A nucleotide. CMGs isolated from the same set of accessions
(EbiaUAi16, Nkwag1Ai17 and Presco2-Ai) showed a transitional mutation A nucleotide at position 100, while other sequences had G. At position 127, a transitional mutation $(\mathrm{C} \leftrightarrow \mathrm{T})$ occurred in which the nucleotide sequences of CMG genomes isolated from the accessions Onyik1Ikw21, Ameka2Ikw22a, Ohankw1Ikw22, EbiaUAi16, Nkwag1Ai17, Presco2_Ai, MileF2Eb22, and Ishie2Eb23 possessed $\mathrm{T}$ nucleotide, while the rest of the sequences, excluding those of EACMV, had C nucleotide. CMGs isolated from accessions Umuom3EzN3 and Umuom4EzN4 possessed T nucleotide at position 128, while the rest had C. Similarly, CMGs isolated from the accessions Umuom4EzN4, MileF2Eb22, and Ishie2Eb23 showed a transversional mutation G-T at position 129 . The accessions, Onyik1Ikw21, Ameka2Ikw22a, and Ohankw1Ikw22 revealed T nucleotide at 132 position, while the rest of the ACMV isolates from the remaining accessions showed C. At consensus position of 156, only Onyik1Ikw21, Ameka2Ikw22a, and Ohankw1Ikw22 had $\mathrm{T}$, while the rest of the ACMV sequences had G, due to transversional mutation $(\mathrm{G} / \mathrm{T})$. Within the position of 187, another transversional mutation occurred with EbiaUAi16, Nkwag1Ai17 and Presco2_Ai possessing $\mathrm{G}$ nucleotide in place of $\mathrm{T}$ that was associated with other isolate sequences. Considering positions 193 and 199, Umuom1EzN18 and Umuom2EzN19 had A and G nucleotides, while the rest of the sequences showed $\mathrm{G}$ and A, respectively.

Also, at consensus positions 217 and 223, the cassava accessions Amuzu1EzS5, Onuek1EzS6, and Onuek10EzS had T nucleotide, while the rest of the isolates had C. At 226 position, Onueb2Izzi13, Ugwua1Eb9, Ohau2Izhia, Ohau3Izhia, EbiaUAi16, Nkwag1Ai17, Presco2_Ai, 


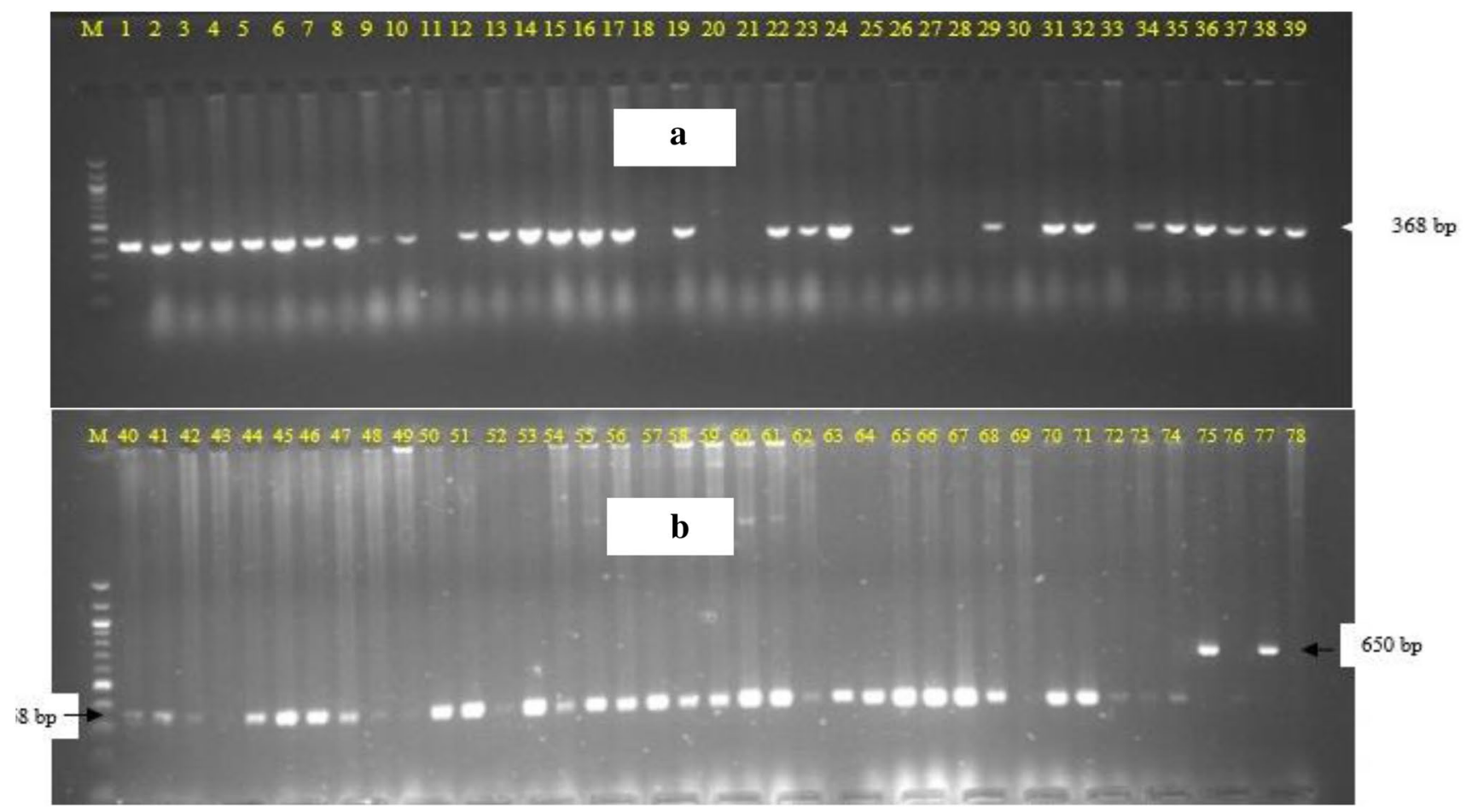

Fig. 4 Detection of African cassava mosaic virus (ACMV) (368 bp) using multiplex-polymerase chain reaction. a $M 100$ bp step DNA ladder, 1 Obubara1, 2 Obubara2, 3 Obubara3, 4 Obegu Mbara1, 5 Onuebonyi1, 6 Onuebonyi2, 7 Onuebonyi3, 8 Onuebonyi4, 9 Ebia Unuphu1, 10 Ebia Unuphu2, 11 Ebia Unuphu3 (negative control), 12Ebia Unuphu4, 13 Umuome1, 14 Umuome2, 15 Umuome3, 16 Umuome4, 17 Amuzu1, 18 Amuzu2 (negative control), 19 Amuzu3, 20 Amuzu4 (negative control), 21 Onyikwal(negative control), 22 Onyikwa2, 23 Onueke1, 24 Onueke2, 25 Onueke3 (negative control), 26 Onueke4, 27 Onueke5 (negative control), 28 Onueke6 (negative control), 29 Onueke7, 30 Onueke8 (negative control), 31 Onueke9, 32 Onueke10, 33 Amekal (negative control), 34

MileF2Eb22, and Ishie2Eb23 were linked to A nucleotide, while the rest had G. Accessions Nwakp1Ikw7, Obuba1Izzi1, Obuba1Izzi2, Onyik1Ikw21, Ameka2Ikw22a, Ohankw1Ikw22, Umuom3EzN3, Umuom4EzN4, AfikpoNAma3, AfikpoS3Eda, AfikpoS4Eda, and AfikpoN1N11 had G nucleotide at 231 position, while the remaining ones had $\mathrm{T}$ at the same position. At 259, Onyik1Ikw21, Ameka2Ikw22a, and Ohankw1Ikw22 showed $\mathrm{T}$, but the remaining ones had $\mathrm{C}$ nucleotide. The accessions, AfikpoNAma3, AfikpoS3Eda, AfikpoS4Eda, and AfikpoN1N11 had A nucleotide at 265 position, and $\mathrm{T}$ nucleotide at the same position for other sequences. Considering EACMV representative sequences, there were various polymorphisms at different consensus positions when aligned with ACMV sequences but no variations when the two EACMV isolate sequences were compared (Supplementary Fig. S1).

For the translated sequences of ACMV from the representative cassava accessions, variants of the virus were
Ameka2, 35 Ameka3, 36 Ameka4, 37 Onyikwa1, 38 Ohankwu1, 39 Ohankwu2; and b $M 100$ bp step DNA ladder; 40 Ohankwu3; 41 Nwakpu1, 42 Nwakpu2, 43 Nkwagu1, 44 Nkwagu2, 45 Presco1, 46 Presco2, 47 Presco3, 48 Presco4, 49 Presco5, 50 Presco6, 51 Presco7, 52 Ugwuachara1, 53 Ugwuachara2, 54 Ugwuachara3, 55 Ugwuachara4, 56 Ugwuachara5, 57 Abaomege 1, 58 Mile four1, 59 Mile four2, 60 Ishieke1, 61 Ishieke2, 62 Ishieke3, 63 Ishieke junction, 64 Ohaukwu1, 65 Ohaukwu2, 66 Ohaukwu3, 67 Afikpo North1, 68 Afikpo North2, 69 Amasiri3 (negative control), 70 Amasiri1, 71 Afikpo South1, 72 Afikpo South2, 73 Afikpo South3, 74 Afikpo South4, 75 Afikpo North3, 76 Amasiri2, 77 Afikpo North4, 78 Ugwuachara6

identified at four different consensus positions (Supplementary Fig. S2). At positions 54 and 62, Onyik1Ikw21, Ameka2Ikw22a, Ohankw1Ikw22 and Nwakp1Ikw7 demonstrated a nonsynonymous mutation by possessing Isoleucine (I), while the remaining ACMV translated sequences of the cassava accessions had Leucine (L). Also, at consensus position 62, the same set of accessions (Onyik1Ikw21, Ameka2Ikw22a, Ohankw1Ikw22 and Nwakp1Ikw7) had a mutation by possessing Isoleucine (I), while the remaining cassava accessions had Valine (V). The accessions, Umuom3EzN3 and Umuom4EzN4, had Lysine (K), while the remaining accessions showed Arginine (R) at 63 . At 87 position, Amuzu1EzS5, Onuek1EzS6, and Onuek10EzS had Methionine (M), while the remaining translated sequences exhibited a different amino acid, I. The sequences from accessions that tested positive to EACMV were not shown here because there was no variation (synonymous mutation) after the translation. 


\section{NCBI BLAST output and pairwise comparisons of the sequenced representatives of symptomatic Manihot esculenta accessions}

To further confirm the nature of the virus infection expressed on the sampled M. esculenta, representative samples from the sampled locations were selected, purified and sequenced. Sequencing further confirmed the presence of ACMV and EACMV, respectively. The Bit scores of total coverage, e-value and percentage identity ranged from 84 to $100,7.00 \mathrm{e}^{-148}$ to $0.00 \mathrm{e}^{+00}$, and $91.13-99.07 \%$, respectively (Table 3). For ACMV, the identified species of DNA-A genome had high percentage similarity of nucleotide sequences to the ones from different countries including Nigeria, Uganda, Angola, Ghana, Madagascar, and Central African Republic, while the detected EACMV was similar to that of Cameroon strain, with $92.14 \%$ identity. Pairwise sequence comparisons produced $91-100 \%$ pairwise identity within the ACMV isolates in comparison with the reference sequences, while EACMV yielded $>89 \%$ identity when compared to the Cameroon reference strain (Fig. 5).

\section{Phylogenetic reconstruction of the sequenced representatives of symptomatic Manihot esculenta accessions}

Phylogenetic reconstruction using Maximum Likelihood method resolved the sequences into five groups (Fig. 6). Group I consisted of 9 accessions from different LGAs including Ebonyi (Ugwua1Eb9), Ohaukwu (Ohau2Izhia, Ohau3Izhia), Izzi (Onueb2Izzi13) and they clustered with a known ACMV reference sequence from Cameroon. Group II contained a known NCBI reference sequence from Madagascar and it clustered with accessions

Table 3 BLAST results from sequencing of representatives of phenotypically evaluated Musa esculenta cultivars

\begin{tabular}{|c|c|c|c|c|c|c|c|c|}
\hline Sequence IDs & Location & Total score & $\begin{array}{l}\text { Query } \\
\text { coverage } \\
(\%)\end{array}$ & e-value & \%identity & Acession No & NCBI Hits & Country \\
\hline Obuba1Izzi1 & Obubara 1 & 534 & 99 & $7.00 \mathrm{e}^{-148}$ & 96.88 & EU685318 & ACMV & Nigeria \\
\hline ObegM1Izzi2 & Obegu Mabara 1 & 534 & 99 & $7.00 \mathrm{e}^{-148}$ & 96.88 & EU685318 & ACMV & Nigeria \\
\hline AfikpoNAma3 & Amasiri 3 & 534 & 99 & $8.00 \mathrm{e}^{-148}$ & 97.15 & EU685318 & ACMV & Nigeria \\
\hline AfikpoS3Eda & Edda 3 & 534 & 99 & $8.00 \mathrm{e}^{-148}$ & 97.15 & EU685318 & ACMV & Nigeria \\
\hline AfikpoS4Eda & Edda 4 & 534 & 99 & $8.00 \mathrm{e}^{-148}$ & 97.15 & EU685318 & ACMV & Nigeria \\
\hline Onueb2Izzi13 & Onuebonyi 2 & 558 & 99 & $3.00 \mathrm{e}^{-155}$ & 98 & HE979765 & ACMV & Uganda \\
\hline Ameka2Ikw22a & Ameka 2 & 520 & 99 & $2.00 \mathrm{e}^{-143}$ & 95.95 & EU685318 & ACMV & Nigeria \\
\hline Ohankw1Ikw22 & Ohankwu 1 & 520 & 99 & $2.00 \mathrm{e}^{-143}$ & 95.95 & EU685318 & ACMV & Nigeria \\
\hline Umuom1EzN18 & Umuome 1 & 540 & 99 & $2.00 \mathrm{e}^{-149}$ & 96.90 & GU580897 & ACMV & Angola \\
\hline Umuom2EzN19 & Umuome 2 & 540 & 99 & $2.00 \mathrm{e}^{-146}$ & 96.90 & GU580897 & ACMV & Angola \\
\hline AfikpoN1N11 & Afikpo North 1 & 534 & 99 & $8.00 \mathrm{e}^{-148}$ & 97.15 & EU685318 & ACMV & Nigeria \\
\hline Onyik1Ikw21 & Onyikwa 1 & 520 & 99 & $2.00 \mathrm{e}^{-143}$ & 95.95 & EU685318 & ACMV & Nigeria \\
\hline Nwakp1Ikw7 & Nwakpu 1 & 460 & 98 & $1.00 \mathrm{e}^{-125}$ & 92.79 & KJ887790 & ACMV & Madagascar \\
\hline Umuom3EzN3 & Umuome 3 & 542 & 99 & $4.00 \mathrm{e}^{-150}$ & 96.91 & MG250142 & ACMV & Ghana \\
\hline Onuek10EzS & Onueke 10 & 531 & 100 & $1.00 \mathrm{e}^{-146}$ & 96.30 & EU685322 & ACMV & Nigeria \\
\hline Umuom4EzN4 & Umuome 4 & 542 & 99 & $4.00 \mathrm{e}^{-150}$ & 96.91 & MG250142 & ACMV & Ghana \\
\hline Amuzu1EzS5 & Amuzu 1 & 531 & 100 & $1.00 \mathrm{e}^{-146}$ & 96.30 & EU685322 & ACMV & Nigeria \\
\hline Onuek1EzS6 & Onueke 1 & 520 & 100 & $2.00 \mathrm{e}^{-143}$ & 95.68 & HE979766 & ACMV & Uganda \\
\hline Ugwua1Eb9 & Ugwuachara 1 & 575 & 99 & $4.00 \mathrm{e}^{-160}$ & 99.07 & EU685318 & ACMV & Nigeria \\
\hline Ohau2Izhia & Izhia 2 & 575 & 99 & $4.00 \mathrm{e}^{-160}$ & 99.07 & EU685318 & ACMV & Nigeria \\
\hline EbiaU1Ai16 & Ebia Unuhpu 1 & 555 & 98 & $6.00 \mathrm{e}^{-154}$ & 98.11 & KJ887779 & ACMV & Central African Republic \\
\hline Nkwag1Ai17 & Nkwagu 1 & 555 & 98 & $6.00 \mathrm{e}^{-154}$ & 98.11 & KJ887779 & ACMV & Central African Republic \\
\hline MileF2Eb22 & Mile four 2 & 534 & 99 & $7.00 \mathrm{e}^{-148}$ & 96.88 & GU580897 & ACMV & Angola \\
\hline Ishie2Eb23 & Ishieke 2 & 534 & 99 & $7.00 \mathrm{e}^{-148}$ & 96.88 & GU580897 & ACMV & Angola \\
\hline Ohau3Izhia & Izhia 3 & 575 & 99 & $4.00 \mathrm{e}^{-160}$ & 99.07 & EU685318 & ACMV & Nigeria \\
\hline Presco2-Ai & Presco 2 & 555 & 98 & $6.00 \mathrm{e}^{-154}$ & 98.11 & KJ887779 & ACMV & Central African Republic \\
\hline AfikpoN3_N13 & 713 & 713 & 84 & $0.00 \mathrm{e}^{+00}$ & 92.14 & AY211887 & EACMV & Cameroon \\
\hline AfikpoN4_N12 & 713 & 713 & 84 & $0.00 \mathrm{e}^{+00}$ & 92.14 & AY211887 & EACMV & Cameroon \\
\hline
\end{tabular}

$A C M V$ African Mosaic Virus, EACMV East African Mosaic Virus, NCBI National Center for Biotechnology Information 


EU685318_ACMVNG
FM877473_ACMVBurkinaFaso
HE979765_ACMVUG
AF366902ACMVCameroon
KJ887884_ACMVMG
HE814062_ACMVCARBambari
Umuom3EzN3
Umuom4EzN4
EbiaU1Ai16
Nkwag1Ai17
Presco2_Ai
Ishie2Eb23
MileF2Eb22
JQ804864_ACMVRep_
Ohau2lzhia
Onueb2lzzi13
Ohau3lzhia
Ugwua1Eb9
Umuom1EzN18
Umuom2EzN19
Amuzu1EzS5
Onuek10EzS
Onuek1EzS6
Obegli1lzzi2
Obuba1lzzi1
AfikpoN1N11
AfikpoNAma3
AfikpoS3Eda
AfikpoS4Eda
Ameka2lkw22a
Ohankw1lkw22
Onyik1lkw21
Nwakp1lkw7
AfikpoN3_N13
AfikpoN4_N12
AJ006458_EACMVKenya
AY211887_EACMVKOAV2
AF112354_EACMVCameroon
EU685319_EACMCVNG
AF259896_EACMVCameroon
A.J717532_EACMVUganda
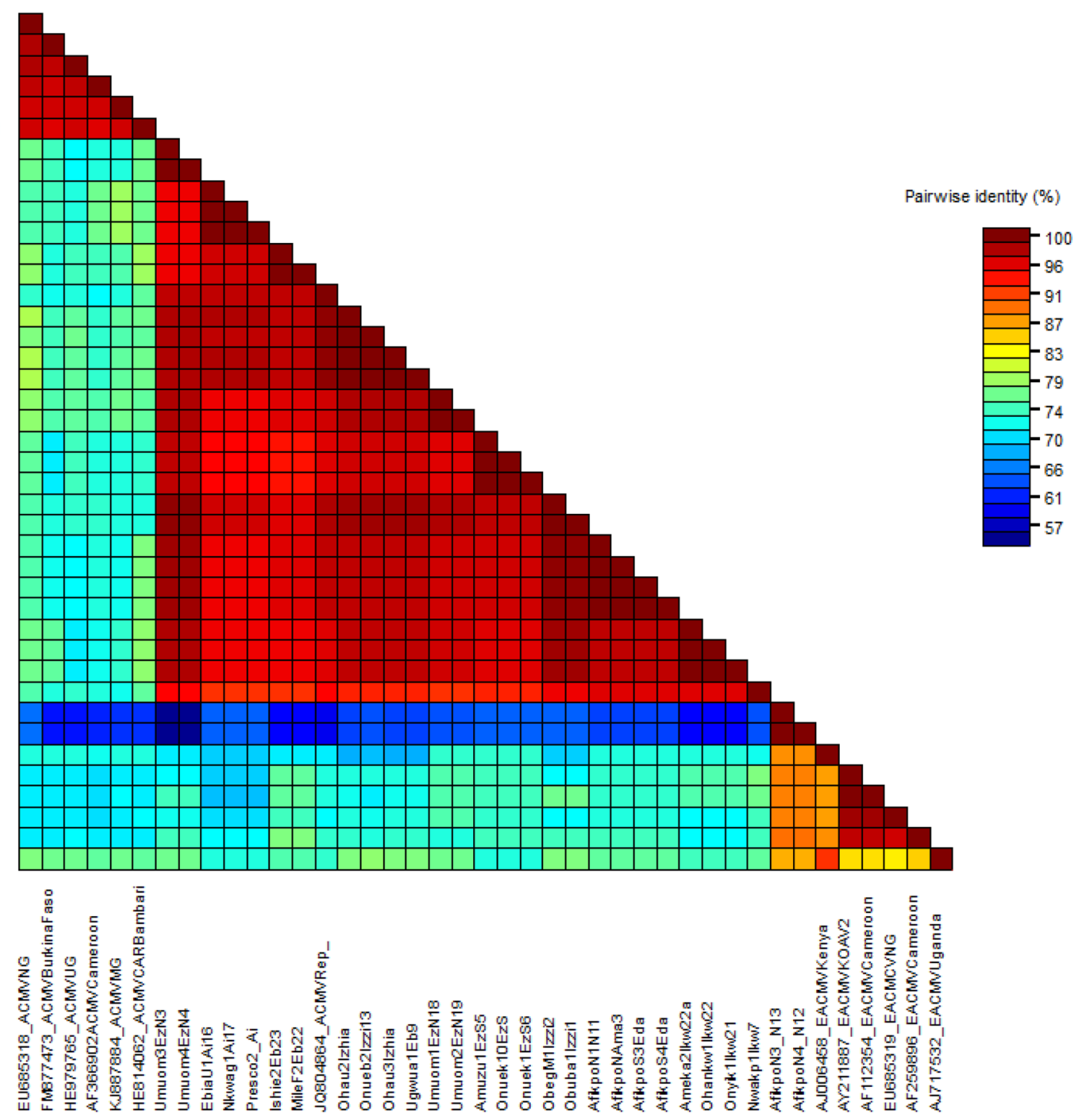

Fig. 5 Pairwise sequence comparisons of representative sequences from African cassava mosaic virus and East Africa cassava mosaic virus isolates. Sequences corresponding to the same species based on a $94 \%$ cutoff are highlighted with the same colour. (Colour figure online)

from Ebonyi (MileF2Eb22, Ishie2Eb23) and Abakaliki (Presco2_Ai, EbiaU1Ai16, Nkwag1Ai17). For the group III, Umuom3EzN3 and Umuom4EzN4 accessions got grouped with NCBI retrieved ACMV reference sequences from Ghana, Nigeria, Uganda and Burkina Faso but they seemed to be more closely related to the one from Ghana (MG250137_ACMV_GH). In group IV, AfikpoN3_13 and AfikpoN4_12 clustered with other known EACMV reference sequences from Kenya, Uganda, Cameroon and Nigeria. Group V contained the highest number of cassava accessions from various LGAs as Ikwo (Onyik1Ikw21, Ohankw1Ikw22, Ameka2Ikw22a, Nwakp1Ikw7), Afikpo North (AfikpoNAma3, AfikpoN1N11, AfikpoS3Eda, AfikpoS4Eda), Izzi (Obuba1Izzi1, ObegM1Izzi2), Ezza North (Umuom1EzN18, Umuom2EzN19) and Ezza South
(Onuek1EzS6, Amuzu1EzS5, Onuek10EzS), and they were clustered with ACMV reference sequence from Central African Republic (JQ804864_ACMV_Rep). The outgroup used in reconstructing the phylogenetic trees was a sequence of Pentalonia nigronervosa that was retrieved from NCBI database. The out-group separated disntictly from other sequences.

\section{Discussion}

Knowledge of the status of CMD among the major cassava growning zones in Ebonyi State is very essential in order to establish appropriate control strategies and phytosanitary measures to contain its spread. It has been demonstrated that 


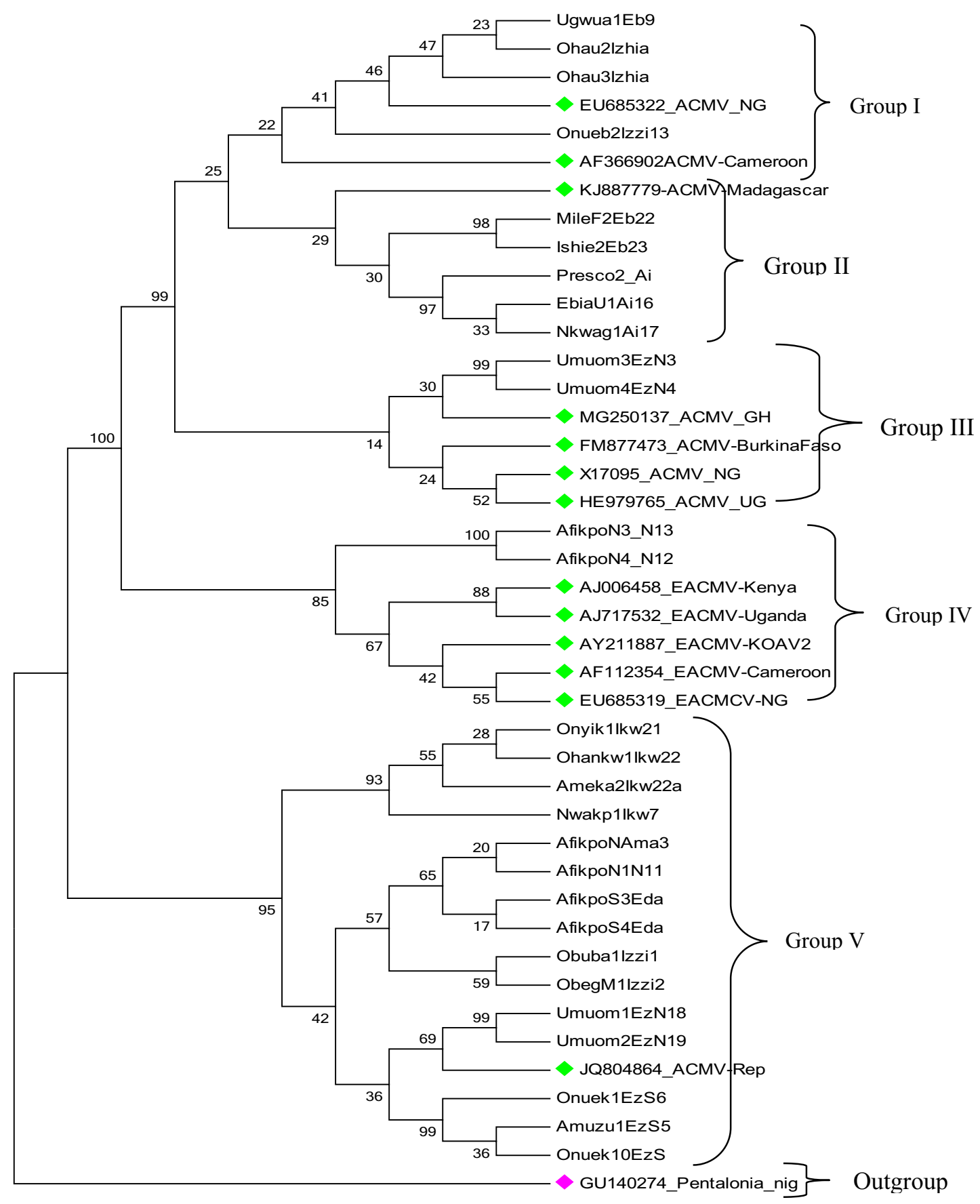

Fig. 6 Molecular phylogenetic analysis of representative sequences of cassava mosaic disease (CMD) of cassava accessions using Maximum Likelihood method

the presence of cassava varieties that are susceptible to CMD in farmers' fields resulted in huge economic loss and drastic reduction in productivity [22].

This study identified evident symptomatic expressions (mild chlorotic patterns; leaf distortion; mosaic pattern on leaves; general reduction in leaf size; misshapen twisted leaves; and stunting of the whole plant) of CMD on the cassava leaves virtually in all the sampled locations in different
LGAs of Ebonyi State, and the scored symptoms were similar to the previously reported ones [39, 48-51]. Considering the status of CMD in the studied LGAs, the highest mean percentage incidence of RE (11\%) was identified in Afikpo North, followed by Ebonyi LGA (2\%); Ezza South (1\%); Izzi, Abakaliki and Ikwo with $0.1 \%$ each, but there was no RE expression on cassava leaves obtained from Ezza North, Ohaukwu, Afikpo South and Onicha, indicating that most 
of the farmers' fields have been exposed to the CMD epidemic. This was further supported by high mean incidences of SU (17-100\%), and HS (27-66\%) that were detected on the cassava leaves in most of the LGAs. The TO symptom expression was frequent and detected in all the locations, except Onicha LGA. The mean incidence of TO across the LGAs (except Onicha), ranged from 12 to 53\%. This study revealed high incidences of CMD due to higher proportion of SU (scale 4) and HS (scale 5) compared to RE (scale 1) symptoms on most of the cassava accessions from different LGAs. This could possibly be linked to the use of highly infected cassava cuttings as planting materials by the local farmers. Using and recycling of infected cassava cuttings have been adjudged to have a strong relationship with elevated severity incidence of CMD [22, 23, 52, 53]. The cause of this widespread distribution of CMD could be attributed to the presence of $B$. tabaci since most of the local farmers do not have enough capital to afford insecticides for management of the insect vector, and possible existence of different strains of ACMV in the sampled locations. It could also be linked to the sources and nature of cassava cuttings utilized by the local farmers since most of the local farmers do not have access to different improved cassava varieties that are resistant to CMD infection as earlier reported [29, 51]. The activities of $B$. tabaci coupled with the use and distribution of highly CMD susceptible varieties as well as recycling of infected cassava cuttings as planting materials or other possible horizontal transmission strategies have been reported to increase CMD incidence and reduced cassava productivity [23]. Cassava root yield losses associated with the CMD infection has been estimated to be up to $100 \%$ in susceptible varieties in cassava growing regions $[33,54]$.

The multiplex-PCR data confirmed the phenotypically identified CMD in the cassava accessions and also confirmed the negative controls. The multiplex PCR result equally confirmed the presence of both ACMV and EACMV in the samples (Afikpo North 3 and Afikpo North 4) from Afikpo North LGA. This study shows that the ACMV strain is more dominant compared to the EACMV in all the sampled locations of Ebonyi State. We therefore recommend that adequate care should be exercised by farmers in sourcing cassava cuttings as planting materials from such vulnerable locations to mitigate further spread of EACMV strain and have only ACMV to contend with. This is vital since mixed infections resulting from ACMV and EACMV have been reported to cause more damage than single infections in cassava production zones [50, 55-57]. However, the absence or low level of high to moderate infection on cassava plants in some LGAs (Izzi, Abakaliki, Ikwo, Ezza South, and Ebonyi) could be linked to low adoption of RE and MR cassava accessions by farmers, reduced number (low population) of the virus vector ( $B$. tabaci) or delayed disease development prior to the sample collection [58]. Previous reports have shown the presence of ACMV and EACMV in Nigeria [39, 48, 59, 60].

DNA sequencing of the representatives of the samples further validated the existence of ACMV and EACMV types of CMD in the studied locations. Different variants of ACMV were obtained based on variable mutations at different consensus positions at both nucleotide and amino acid levels. Variants of ACMV displaying different mosaic patterns have been reported [48]. At nucleotide level of both ACMV and EACMV, the result revealed that transitional mutations were more frequent than transversions, but there was no variation between the two sequences of EACMV. Similar higher proportion of transitions has been reported in naturally infected cassava accessions under field conditions [61]. The occurrence of $\mathrm{C} \leftrightarrow \mathrm{T}$ and $\mathrm{G} \leftrightarrow \mathrm{A}$ substitutions have been accounted for by deamination effects and the significance of deamination in virus mutagenesis could possibly be attributed to the presence of deaminating enzymes in plant nuclei [62-64]. At amino acid level, mutations in ACMV representative sequences from three LGAs were nonsynonymous, in which accessions from Ikwo, Ezza North and Ezza South had I, K and M, respectively at three various consensus positions instead of $\mathrm{L}, \mathrm{R}$ and I amino acids that were found among the other remaining accessions. However, use of infected cuttings as planting materials or $B$. tabaci population could be the possible factors responsible for the disproportionate distribution of the CMD within the sampled LGAs of Ebonyi State, rather than mutations or variations in CMGs that could cause severer symptoms and more devastating effects in the farmers' fields. Existence of variants of CMD or existence of new pathogen due to mutations could jeopardise cassava productivity and possibly retedard economic development in growing locations as earlier reported $[24,26]$. The existing variations could be attributed to a high rate of mutation associated with cassava geminiviruses in which a single clone could quickly transform into a collection of mutant sequences when introduced into the suitable host [61]. BLAST analysis further validated the CMD status as ACMV and EACMV, revealing the percentage identities of ACMV (92.79-99.07\%) to be similar to the known ones from Nigeria, Uganda, Ghana, Angola, Madagascar and Central African Republic, while the EACMV had percentage (92.14\%) and pairwise (> 89\%) identities of known Cameroon strain.

Phylogeny resolved the sequences into five major groups with most of the accessions dominating group $\mathrm{V}$ with a known reference sequence from Central African Republic. The different clusterings of the ACMV with the known reference sequences from different regions of the world further supports possible existence of variants. The identified EACMV got clustered with the Cameroon strain and other retrieved NCBI known reference sequences from Kenya, Uganda and Nigeria. The spread of these virus 
species could possibly be linked to lack of proper phytosanitary and rapid indexing measures, which lead to exchange of infected materials among the local farmers.

\section{Conclusion}

Our study revealed the presence of of both ACMV and EACMV types of CMD with the ACMV type dominating in the studied locations. ACMV was present in almost all the sampled locations, while EACMV was detected in Afikpo North. High percentage of susceptibility incidence of CMD among the cassava accessions from the three geographical zones of Ebonyi State was very pronounced, with low percentage incidence of resistance to the ACMV. Proactive measures should be taken to forestall further spread of EACMV which incidence is still low in the area to avoid mixed infections that is more devastating than single infection. It is necessary to create awareness of the effects of CMD to the farmers and also educate them on how and where to go for clean (disease-free) planting materials. Constant survelliance and determination of CMD status should be sustained to facilitate decision making and implementation of integrated pest management and control strategies against the disease in Ebonyi State, Nigeria.

Acknowledgements The authors are grateful to Biotechnology Research and Development Center (BRDC), Ebonyi State University, Abakaliki for the provision of research facilities to carry out this work. Also acknowledged here are Onwe Stephen, Egbe Blessing and Egemba Hillary for assisting in the sample collection.

Author contributions All authors were involved in designing the project. DOI, CBA and CAA did the literature search, data extraction, and conducted the work. Data analyses were performed by DOI. DOI developed the first draft of the manuscript and reviewed by CVN, FNN, GNU and BEU. All authors read the manuscript for adequate correction and approved the final copy of it.

Funding No funding was received to conduct this study.

Data availability All data generated in this work are included in this published article [and its supplementary information files] and in GenBank NCBI database [https://www.ncbi.nlm.nih.gov/genbank] where unique sequences with accession numbers MT861185-MT861210 were deposited.

\section{Compliance with ethical standard}

Conflict of interest The authors declare that they have no competing interests.

Ethical approval Consent was verbally obtained from farmers before entering their individual farms for sample collection.

\section{References}

1. Szyniszewska AM (2020) CassavaMap, a fine-resolution disaggregation of cassava production and harvested area in Africa in 2014. Sci Data 7:159. https://doi.org/10.1038/s41597-020-0501-z

2. Karlström A, Calle F, Salazar S, Morante N, Dufour D, Ceballos $\mathrm{H}$ (2016) Biological implications in cassava for the production of amylose-free starch: impact on root yield and related traits. Front Plant Sci 7:604

3. Gedil M, Kumar M, Igwe D (2012) Isolation and characterization of resistant gene analogs in cassava, wild Manihot castor bean (Ricinus communis). Afr J Biotechnol 11(85):15111-15123

4. Haggblade S, Andersson DA, Banda ND, Bergman LJ, Brimer L, Chiona M et al (2012) Cassava commercialization in Southeastern Africa. J Agribus Dev Emerg Econ 2:4-40

5. Malik AI, Kongsil P, Nguyễn VN, Ou W, Sholihin S, Srean P, Sheela MN, López-Lavalle LAB, Utsumi Y, Lu C et al (2020) Breed Sci 70:145-166

6. Egesi CN, Ilona P, Ogbe FO, Akoroda M, Dixon A (2007) Genetic variation and genotype $\times$ environment interaction for yield and other agronomic traits in cassava in Nigeria. Agron $\mathbf{J}$ 99:1137-1142

7. FAO (2010) Report of the twenty second session of the Committee on Agriculture, Rome, 29 November-3 December 2010. Rome

8. FAO (2013) Food and Agricultural Organization [FAO]. Cassava, a 21st Century Crop," Save and Grow Cassava; A guide to sustainable production intensification, food and Agriculture Organization of the United Nations, Rome, pp 1-18

9. FAO (2018) Food and Agricultural Organization [FAO]. Food Outlook-Biannual Report on Global Food Markets-November 2018. Rome. 104 pp. Licence: CC BY-NC-SA 3.0 IGO

10. Legg JP, Kumar LP, Makeshkumar T, Tripath L, Ferguson M, Kanju E, Ntawuruhunga P, Cuellar W (2015) Cassava virus diseases: biology, epidemiology and management. In: Loebenstein G, Nikolaos IK (eds) Advances in virus research. Academic Press, Cambridge

11. Hillocks RJ, Jennings DL (2003) Cassava brown streak disease: a review of present knowledge and research needs. Int J Pest Manag 49:225-234

12. Legg JP, Fauquet CM (2004) Cassava mosaic geminiviruses in Africa. Plant Mol Biol 56:585-599

13. Patil BL, Fauquet CM (2009) Cassava mosaic geminiviruses: actual knowledge and perspectives. Mol Plant Pathol 10:685-701

14. Alabi OJ, Kumar LP, Naidu RA (2008) Multiplex PCR for the detection of African cassava mosaic virus and East African cassava mosaic Cameroon virus in cassava. J Virol Methods 154:111-120

15. Brown J, Fauquet C, Briddon R, Zerbini M, Navas-Castillo J (2011) Family geminiviridae. Elsevier-Academic, Amsterdam

16. Fondong VN (2017) The search for resistance to cassava mosaic geminiviruses: how much we have accomplished, and what lies ahead. Front Plant Sci 8:408

17. Tiendrébéogo F, Lefeuvre P, Hoareau M, Harimalala MA, De Bruyn A, Villemot J, Traoré VSE, Konaté G, Traoré AS, Barro N, Reynaud B, Traoré O, Lett J-M (2012) Evolution of African cassava mosaic virus by recombination between bipartite and monopartite begomoviruses. Virol J 9:67

18. Harimalala M, Lefeuvre P, De Bruyn A, Tiendrébéogo F, Hoareau M, Villemot J, Ranomenjanahary S, Andrianjaka A, Reynaud B, Lett J-M (2012) A novel cassava-infecting begomovirus from Madagascar: Cassava mosaic Madagascar virus. Arch Virol 157:2027-2030

19. De Bruyn A, Harimalala M, Zinga I, Mabvakure BM, Hoareau M, Ravigné V, Walters M, Reynaud B, Varsani A, Harkins GW, Martin DP, Lett J-M, Lefeuvre P (2016) Divergent evolutionary 
and epidemiological dynamics of cassava mosaic geminiviruses in Madagascar. BMC Evol Biol 16:182

20. Wagaba H, Beyene G, Trembley C, Alicai T, Fauquet CM, Taylor NJ (2013) Efficient transmission of Cassava brown streak disease viral pathogens by chip bud grafting. BMC Res Notes 6:516

21. Fauquet C, Mayo M, Maniloff J, Desselberger U, Ball L (2005) Virus taxonomy VIIIth report of the international committee on taxonomy of viruses. Elsevier/Academic, London, p 1162

22. Fauquet C, Fargette D (1990) Cassava mosaic virus/etiology, epidemiology, and control. Plant Dis 74:404-411

23. IITA (2010) Cassava disease surveillance surveys, annual survey 2009 Maps report final. International Institute for Tropical Agriculture, 2010

24. Okogbenin E, Egesi CN, Olasanmi B, Ogundapo O, Kahya S, Hurtado P, Marin J, Akinbo O, Mba C, Gomez H, de Vicente C, Baiyeri S, Uguru M, Ewa F, Fregene M (2012) Molecular marker analysis and validation of resistance to Cassava mosaic disease in elite cassava genotypes in Nigeria. Crop Sci 52:2576-2586

25. Kuon J-E, Qi W, Schläpfer P, Hirsch-Hoffmann M, von Bieberstein PR, Patrignani A, Poveda L, Grob S, Keller M, ShimizuInatsugi R, Grossniklaus U, Vanderschuren H, Gruissem W (2019) Haplotype-resolved genomes of geminivirus-resistant and geminivirus susceptible African cassava cultivars. BMC Biol 17:75

26. Asare PA, Galyuon IKA, Asare B, Srfo JK, Tetteh JP (2014) Phenotypic and molecular screening of cassava (Manihot esculenta Crantz) cultivars for resistance to cassava mosaic disease. J Gen Mol Virol 6:6-18

27. Rwegasira GM, Chrissie MER (2015) Efficiency of non-vector methods of Cassava brown streak virus transmission to susceptible cassava plants. Afr J Food Agr Nut Dev 15:1684-5374

28. Otim-Nape GM, Shaw MW, Thresh JM (1994) The effects of African cassava mosaic geminivirus on the growth and yield of cassava in Uganda. Trop Sci 34:43-54

29. Akano AO, Dixon AGO, Mba C, Barrera E, Fregene M (2002) Genetic mapping of a dominant gene conferring resistance to cassava mosaic disease. Theor Appl Genet 105:521-525

30. Atiri GI, Ogbe FO, Dixon AGO, Winter S, Ariyo O (2004) Status of Cassava mosaic virus diseases and cassava begomoviruses in sub-Saharan Africa (SSA). J Sustain Agric 24:5-35

31. Rabbi IY, Hamblin MT, Kumar PL, Gedil MA, Ikpan AS, Jannink JL, Kulakow PA (2014) High-resolution mapping of resistance to cassava mosaic geminiviruses in cassava using genotyping-bysequencing and its implications for breeding. Virus Res 186:87-96

32. Hounguea JA, Zandjanakou-Tachin M, Ngalle HB, Pita JS, Cacaï GHT, Ngatat SE, Bell JM, Ahanhanzo C (2019) Evaluation of resistance to cassava mosaic disease in selected African cassava cultivars using combined molecular and greenhouse grafting tools. Physiol Mol Plant Pathol 105:47-53

33. Thresh JM, Otim-Nape GW, Legg JP, Fargette D (1997) African cassava mosaic virus disease: the magnitude of the problem. Afr J Root Tuber Crops 2:13-18

34. Owor B, Legg JP, Okao-Okuja G, Obonyo R, Ogenga-Latigo MW (2004) The effect of cassava mosaic geminiviruses on symptom severity, growth and root yield of cassava mosaic virus diseasesusceptible cultivar in Uganda. Ann Appl Biol 145:331-337

35. Thottappilly G, Thresh JM, Calvert LA, Winter S (2003) Cassava. In: Loebenstein G, Thottappilly G (eds) Virus and virus-like diseases of major crops in developing countries. Kluwer Academic Publ, Dordrecht, pp 107-165

36. Terry ER (1975) Description and evaluation of cassava mosaic disease in Africa. In: Terry ER, MacIntyre R (eds) The international exchange and testing of cassava germplasm in Africa. IITA, Ibadan, pp 53-54
37. Lokko Y, Danquah EY, Offei SK, Dixon AGO, Gedil MA (2005) Molecular markers associated with a new source of resistance to the cassava mosaic disease. Afr J Biotechnol 4:873-881

38. Abarshi MM, Mohammed IU, Wasswa P, Hillocks RJ, Holt J, Legg JP, Seal SE, Maruthi MN (2010) Optimization of diagnostic RT-PCR protocols and sampling procedures for the reliable and cost-effective detection of Cassava brown streak virus. J Virol Methods 163:353-359

39. Alabi OJ, Ogbe FO, Bandyopadhyay R, Kumar PL, Dixson AGO, Hughes JD, Naidu RA (2008) Alternative hosts of African cassava mosaic virus and East African cassava mosaic Cameroon virus in Nigeria. Arch Virol 153:1743-1747

40. Kumar PL, Legg JP (2009) IITA Laboratory manual for the diagnosis of cassava virus diseases, by P.L. Kumar and J.P. Legg, eds. Ibadan

41. Thresh JM, Fargette D (2001) The epidemiology of African plant viruses: basic principles and concepts. In: J. d'A. Hughes and B. O. Odu, (eds) Proceedings of Plant Virology in Sub-Saharan Africa. Intl Inst Trop Agric Ibadan, pp 61-111

42. Mulenga RM, Legg JP, Ndunguru J, Chikoti PC, Miano DW, Mutitu WE, Alabi OJ (2016) Survey, molecular detection, and characterization of geminiviruses associated with cassava mosaic disease in Zambia. Plant Dis 100:1379-1387

43. Hall TA (2013) BioEdit, version 725; software for biological sequence alignment. Ibis Biosciences, Carlsbad

44. Kumar S, Stecher G, Li M, Knyaz C, Tamura K (2018) MEGA $\mathrm{X}$ : molecular evolutionary genetics analysis across computing platforms. Mol Biol Evol 35:1547-1549

45. Muhire BM, Varsani A, Martin DP (2014) SDT: a virus classification tool based on pairwise sequence alignment and identity calculation. PLoS ONE 9:e108277

46. Edgar RC (2004) MUSCLE: a multiple sequence alignment method with reduced time and space complexity. BMC Bioinform $5: 1-19$

47. Brown JK, Zerbini FM, Navas-Castillo J, Moriones E, RamosSobrinho R, Silva JCF, Fiallo-Olive E, Briddon RW, HernandezZepeda C, Idris A, Malathi VG, Martin DP, Rivera-Bustamante R, Ueda S, Varsan A (2015) Revision of Begomovirus taxonomy based on pairwise sequence comparisons. Arch Virol 160:1593-1619

48. Ogbe FO, Dixon AGO, Hughes JDA, Alabi OJ, Okechukwu R (2006) Status of cassava begomoviruses and their new natural hosts in Nigeria. Plant Dis 90:548-553

49. Elegba W, Appiah AS, Azu E, Afful N, Agbemavor WKS, AgyeiAmponsah J, Owureku-Asare M, Quaye B, Danso KE (2013) Effect of mosaic virus diseases on dry matter content and starch yield of five cassava (Manihot esculenta Crantz) accessions in Ghana. Afr J Biotechnol 12(27):4310-4316

50. Chikoti PC, Ndunguru J, Melis R, Tairo F, Shanahan P, Sseruwagi $P$ (2013) Cassava mosaic disease and associated viruses in Zambia: occurrence and distribution. Int J Pest Manag 59(1):63-72

51. Minato N, Sok S, Chen S, Delaquis E, Phirun I, Le VX, Burra DD, Newby JC, Wyckhuys KAG, de Haan S (2019) Surveillance for Sri Lankan cassava mosaic virus (SLCMV) in Cambodia and Vietnam one year after its initial detection in a single plantation in 2015. PLoS ONE 14(2):e0212780

52. Egesi CN, Ogbe FO, Akoroda M, Ilona P, Dixon AGO (2007) Resistance profile of improved cassava germplasm to cassava mosaic disease in Nigeria. Euphytica 155:215-224

53. Njock TE, Sama V (2015) Quantification and correlation of African cassava mosaic disease parameters on cassava genotypes (Manihot esculenta Crantz) in Buea. Cameroon. GARJAS 4(3):166-172

54. Masinde EA, Ogendo JO, Maruthi MN, Hillocks R, Mulwa RMS, Arama PF (2016) Occurrence and estimated losses caused 
by cassava viruses in Migori County, Kenya. Afr J Agric Res 11:2064-2074

55. Ogbe FO, Atiri I, Robinson D, Dixon AGO, Winter S, Quin FM, Thottappilly G (1999) First report of East African cassava mosaic begomovirus in Nigeria. Plant Dis 83(4):398

56. Offei SK, Owuna-Kwakye M, Thottappilly G (1999) First report of East African cassava mosaic begomovirus in Ghana. Plant Dis 83(9):877

57. Chikoti PC (2011) Development of cassava (Manihot esculenta Crantz) cultivars for resistance to cassava mosaic disease in Zambia. Ph. D thesis, University of KwaZulu-Natal

58. Appiah AS, Amoatey HM, Klu GY, Afful E, Azu E, Owusu GK (2012) Spread of African cassava mosaic virus from cassava (Manihot esculenta Crantz) to physic nut (Jatropha curcas L.) in Ghana. J Phytol 4(1):31-37

59. Ariyo OA, Koerbler M, Dixon AGO, Atiri GI, Winter S (2005) Molecular variability and distribution of cassava mosaic begomoviruses in Nigeria. J Phytopathol 153(4):226-231

60. Abubakar M, Singh D, Keta JN (2019) Cassava mosaic disease and associated geminiviruses in Bauchi State, Nigeria: occurrence and distribution. Am J Plant Biol 4(4):85-90
61. Fondong VN, Chen K (2011) Genetic variability of East African cassava mosaic Cameroon virus (EACMCV) under field and controlled environment conditions. Virol 413:275-282

62. Eritja R, Horowitz DM, Walker PA, Ziehler-Martin JP, Boosalis MS, Goodman MF, Itakura K, Kaplan BE (1986) Synthesis and properties of oligonucleotides containing 2'-deoxynebularine and 2'-deoxyxanthosine. Nucleic Acids Res 14:8135-8153

63. Kamiya H, Shimizu M, Suzuki M, Inoue H, Ohtsuka E (1992) Mutation induced by deoxy xanthosine in codon 12 of a synthetic c-Ha-ras gene. Nucleos Nucleot 11:247-260

64. Stasolla C, Katahira R, Thorpe TA, Ashihara H (2003) Purine and pyrimidine nucleotide metabolism in higher plants. J Plant Phys 160:1271-1295

Publisher's Note Springer Nature remains neutral with regard to jurisdictional claims in published maps and institutional affiliations. 